\title{
Lithuanian Folk Architecture Research as a Repository for the Study of Urban Form
}

\author{
Matas Cirtautas ${ }^{\star}$, Inesa Alistratovaitè-Kurtinaitienè, Dalia Dijokienè \\ Vilnius Gediminas Technical University (VILNIUS TECH), Vilnius, Lithuania
}

Received 2021-10-08; accepted 2022-01-03

\section{Keywords}

Folk architecture, Lithuania, typology of settlements, urban form.

\begin{abstract}
Despite the increasingly global orientation of urban morphology, there still remain countries whose achievements in the field of urban form research are underrepresented. Although the attempts to study settlement form in Lithuania were rather early, the second half of the $20^{\text {th }}$ century was the most productive period. The article presents context, process and findings of the folk architecture research, which became the nurturing environment for the establishment of contemporary urban form studies in Lithuania.
\end{abstract}

\section{Introduction}

In the recent decades, the global focus of urban morphology has become increasingly evident [1]. However, in this rapidly evolving field, there are fewer opportunities to present and discuss the urban form studies in smaller countries, especially, distinguished by relatively late urban development. These remaining 'blind spots' may become distinct cases of urban development trajectories, as well as reveal specific achievements within the broader landscape of urban morphological research. Therefore, there is a need to revisit the process of architectural and urban design knowledge formation in some European countries (e.g. Baltic States) in order to adequately present local processes and outcomes of urban form research to the international audience and, consequently, to stimulate broader comparative studies at regional and global scale.

The article presents the case of Lithuania. Despite the fact that urban development process in Lithuania has been somewhat erratic, it can be divided into five major stages [2]: early (until $15^{\text {th }}$ century), feudal $\left(15^{\text {th }}-\right.$ mid- $19^{\text {th }}$ century), capitalist (mid-19 $9^{\text {th }}-$ mid- $20^{\text {th }}$ century), socialist (1940-1990), and current (since 1990). All the stages have left traces on the network and inner structure of settlements. Although until the mid-20 ${ }^{\text {th }}$ century evolution of urban settlements was tolerably coherent, thereafter the situation has changed considerably. Nevertheless, the realities of the socialist period urged an interest towards national architecture and, subsequently, local urban forms [3].

During the interwar period, the morphology of historical settlements was already regarded as a repository for modern urban design [4], [5], but only in the post-war years the search for a further distinctive path of country's spatial development was inter-linked with the study of cultural heritage, including local architectural and urban traditions. In general, the investigations of urban form in Lithuania during the 1940s-1990s can be divided into two branches: rural and urban. The first one has been anchored in the study of folk architecture, while the second one diffused within a wide range of interrelated practices, such as protection of urban heritage, regeneration of old towns, modelling of urban spatial composition, etc. The aforementioned branches were closely intertwined, because different scientific and practical activities were carried out by the same researchers and organisations and coexisted together. Nevertheless, each of them represents specific topics and chronology of development of urban morphology in Lithuania.

This article presents evolution and findings of the folk architecture research during the second half of the $20^{\text {th }}$ century. It became the nurturing environment for the establishment of modern urban form studies, at first providing first-hand research material and consequently 
laying down methodological foundations for the research of local rural and urban forms. Despite being nearly synonymous with the term 'vernacular architecture', the term 'folk architecture' is preferred in the article due to its broader meaning and direct connotations with population of a country or region, as well as references to their locally rooted culture and lifestyle.

\section{Research Methodology}

The article is a concise summary of the main achievements of folk architecture research, which could be related to the emergence of contemporary study of urban form in Lithuania. The research methodology is purposefully retrospective and based on the overview of literature resources. Further chapters describe general context, goals and process of the folk architecture research, as well as highlight major achievements regarding settlements' form and classification. The research concludes with a discussion, stating the need for further research in order to position the relatively small Lithuanian branch of urban form studies into increasingly global research landscape of urban morphology.

\section{The Context, Objects and Goals of the Research}

The interest in ethnic culture as a major pillar of national identity has sprung already in the interwar period [6]. However, the rise of coordinated research of folk architecture in Lithuania can be associated with the post-war situation in the architectural academia and practice [3]. At that time, execution of architectural research at Kaunas State University was entrusted to young lecturers. Due to the lack of personnel's professional and scientific experience as well as the university's limited technical resources, the humanitiesbased topic of non-professional architectural creativity and its achievements appeared to be a reasonable choice for developing architectural research agenda. In addition to academic, there were also professional motives to closely investigate Lithuanian folk architecture. After the imposition of the 'Iron Curtain', links with European architectural tradition were lost. Under the official doctrine of socialist realism, which stated that architecture and art should be socialist in content and national in its form, an initiative grew to interpret this instruction in the way that enabled search for the manifestations of national form in local architectural and urban traditions. Furthermore, issues concerning the protection of cultural heritage became also relevant. In the context of the country's rapid social and economic transformations in the post-waryears, natural evolution of folk architecture ceased and the long-lasting harmonious coexistence of local population and environment was jeopardized. The latter could be sustained through recognition of folk art in general, purposive heritage preservation, as well as application of local architectural and urban knowledge for spatial development of rural settlements. These academic, professional and heritageoriented motives laid foundations for the entire research methodology. Therefore, the comprehensive study aimed to reveal the country's ethnographic diversity, regional peculiarities and most typical and valuable objects of folk architecture. The outcomes of the research were envisioned to serve the protection of valued examples of folk architecture, educate society, and increase quality of architectural studies.

Although the selected research topic was not new [7], the previous inter-war attempts to analyse historical development and identify characteristic features of rural buildings and homesteads [8] lacked general methodology and common goals. Furthermore, the research material, mainly collected by local ethnographers, did not represent full geographic scope and diversity of folk architecture, therefore, it was inadequate for multi-purpose use and scientific generalization. Due to these shortcomings, the main goals of the study were formulated as follows: seek 1) to determine evolutionary trends and characteristic features of the Lithuanian folk architecture, and 2) to make use of the identified perspective features of folk architecture in the formation of national architecture [3]. The study was oriented to analyse the entire variety of folk architecture objects, including residential, public and other buildings, as well as various urban complexes, such as small towns, villages, and rural homesteads.

\section{Process of the Research}

Chronologically, the process of the Lithuanian folk architecture research in the second half of the $20^{\text {th }}$ century can be divided into three stages (Table I). During the first stage (1947-1958), research material was collected and its initial analysis was performed. This was done mainly through field expeditions, organised despite the then critical post-war conditions, such as insufficient technical equipment, unstable political and economic situation, especially in rural areas (civil war, deportations, collectivisation, etc.). Scientific work was led by Kazys Šešelgis, while the expeditions were supervised by lecturers of the Faculty of Architecture. The goal of the expeditions was, with the help of architecture students, to register and inventory noteworthy objects of folk architecture. The registration was understood as a collection of information, which would allow to decide on the architectural and ethnographic value of the buildings and their groups, as well as to identify the dominant types 
of separate objects and their prevalence in the area under consideration. Only the most representative objects of folk architecture were inventoried, which included photography and accurate measurement of current state of buildings and their complexes, subsequent preparation of detailed drawings and descriptions. While paying less attention to the historical-cultural nature of investigated objects, the applied measures were oriented towards collection of data directly serving architectural design knowledge, such as an explicit architectural form, rational functional, and constructive solutions [3].

During the second stage (1959-1970), research workflow diminished. Expeditions were not organized due to changes in the research agenda of the Faculty of Architecture, as issues of the country's industrialization and urbanization gained momentum and the Faculty's staff were instructed to reorient their activity towards formulation of theoretical foundations for coordination of these processes. Nevertheless, the analysis of previously collected data continued with preparation of reports, dissertations, and research articles. During this period, a two-volume monograph summarizing the findings of the first stage of the Lithuanian folk architecture research was published. Its first volume [9] presented peculiarities of rural settlements and residential buildings, including a typology and characteristics of villages and homesteads, while the second volume [10] discussed spatial structure of towns and architectural features of non-residential buildings and other complexes (e.g. manors).

There were several reasons which led to renewed interest in the folk architecture during the 1970s. First of all, in 1969 a list of protected architectural monuments was drawn up. Secondly, due to the rapid transformation of rural landscape (including historical settlements and their network), an approach towards

\section{TABLE I}

Evolution of Folk Architecture Research in Lithuania during the Second Half of the $20^{\text {th }}$ Century [developed by authors]

\begin{tabular}{|c|c|c|c|c|c|c|c|}
\hline Stage & Main activities & $\begin{array}{l}n \\
\stackrel{n}{ \pm} \\
\text { a }\end{array}$ & 。ั & 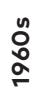 & $\stackrel{n}{\stackrel{n}{a}}$ & $\begin{array}{l}n \\
\stackrel{n}{\infty} \\
\stackrel{\infty}{r}\end{array}$ & 음 \\
\hline First & $\begin{array}{l}\text { Registration and inventory } \\
\text { of valuable objects of } \\
\text { folk architecture (field } \\
\text { expeditions), preliminary } \\
\text { analysis and synthesis of } \\
\text { collected material }\end{array}$ & \multicolumn{2}{|c|}{$\begin{array}{c}1947- \\
1958\end{array}$} & & & & \\
\hline Second & $\begin{array}{l}\text { Structuring and publishing } \\
\text { of results of folk architecture } \\
\text { research }\end{array}$ & \multicolumn{3}{|c|}{$\begin{array}{c}1959 \text { - } \\
1970\end{array}$} & & & \\
\hline Third & $\begin{array}{l}\text { Detailed investigation } \\
\text { and inventory (including } \\
\text { field expeditions) of folk } \\
\text { architecture monuments }\end{array}$ & & & & \multicolumn{2}{|c|}{$\begin{array}{c}1971- \\
1988\end{array}$} & \\
\hline
\end{tabular}

preservation of heritage of folk architecture shifted. A perception was formed that detailed investigation of architectural objects, including field expeditions, was a significant measure for both protection and establishment of the general repository of the country's ethno-cultural legacy. Therefore, during the third stage (1971-1988), under an updated methodology [11] the focus was laid only on the declared monuments of folk architecture, including analysis of their evolution and inventory of their current state and discontinuing the search of new cases. Interestingly, the priority was given to the analysis of historical villages, arguing that they encompass the largest quantity and variety of types of traditional rural buildings and homesteads in a particular ethnographic area. In addition, it was considered that a comprehensive survey of villages would better illustrate former socioeconomic trends of Lithuania's development and their impact on folk architecture. Moreover, the degradation of spatial structure of historical rural settlements has been regarded as a more dangerous trend than the transformation of individual buildings or homesteads, leading to irreversible loss of valuable information about the Lithuanian folk architecture. In general, the village was considered as a territorial, social, economic, and architectural entity, while the settlement area - as an architectural complex - was its major component. Therefore, investigation included not only homesteads and their buildings, but also the development of the settlement, its demographic and economic characteristics, the plan and spatial structure, as well as the surrounding land scape, aiming to disclose possible contradictions and synthesis between original (traditional) and contemporary structures. This complex approach is reflected in the five-volume monograph presenting outcomes of the folk architecture research during the 1970s-1980s. The first volume is dedicated to Zervynai village [12]. The subsequent volumes present characteristics of small scattered villages [13], spontaneous villages [14], one-street villages in the south-eastern Lithuania [15], and one-street and standalone farm villages in Aukštaitija ethnographic region [16].

During the first decades of the post-war period, intensified research and collection of associated material revealed a growing interest in the heritage of the Lithuanian folk culture. These activities were carried out not only by expeditions organized by Kaunas State University and later Kaunas Polytechnic Institute (current Kaunas University of Technology), and Vilnius Civil Engineering Institute (current Vilnius Gediminas Technical University). Other organisations have contributed to this work as well, e.g. the Department of Archaeology and Ethnography of the Institute of History and Ethnography of the Academy of Sciences, Museum of History and Ethnography, Museum of Art and Regional 
Studies, the Department of Architecture of the Institute of Architecture and Construction of Kaunas branch of the Academy of Sciences, the Society for the Regional Studies and Protection of Monuments. However, due to the negative approach of political authorities towards manifestations of Lithuanian nationalism, these fruitful activities of ethnographers and other researchers later were restricted. Nevertheless, ethnographers still have managed to collect and publish a lot of material about the Lithuanian folk architecture. The topic attracted interest of foreign ethnographers as well.

Ethnographers' theoretical works and publications have undoubtedly expanded knowledge about folk architecture, especially the evolution of rural homesteads and their buildings. However, the research objects were frequently chosen based on their historical and material characteristics. With the intention of architects to use the research findings in architectural practice, the inventory cases were selected according to different criteria, such as the object's artistic expression and the level of folk artists' contribution. Furthermore, homesteads, villages, and other elements of rural and pre-urban settlements were investigated as integral spatial complexes [3].

\section{Major Findings of the Research}

\section{A. Peculiarities of Rural Settlements}

One of the major achievements of the study of Lithuanian folk architecture during the second half of the $20^{\text {th }}$ century is the retrospective classification of rural settlements. Although there were previous attempts to classify rural settlements in Lithuania [17]-[21], these proposals were inaccurate due to deficiencies in the analysed material and approaches to features of settlement form [9]. Therefore, in order to define the most common types of settlements' physical structure, researchers carried out detailed analysis of historical cartographic maps and organized field trips. Plan structure, grouping and form of homesteads were considered as key attributes for settlement classification. The following three most frequent forms of rural settlements in the Lithuanian territory were identified: scattered, onestreet and standalone farm villages (Table II). Additional criteria (e.g. size of the settlement) were used to define subgroups and variations.

The scattered rural settlements are characterised by an irregular street network and compact homesteads of various forms. Depending on the amount of homesteads and the

TABLE II

Types of Rural Settlements (Villages) [9, 19]

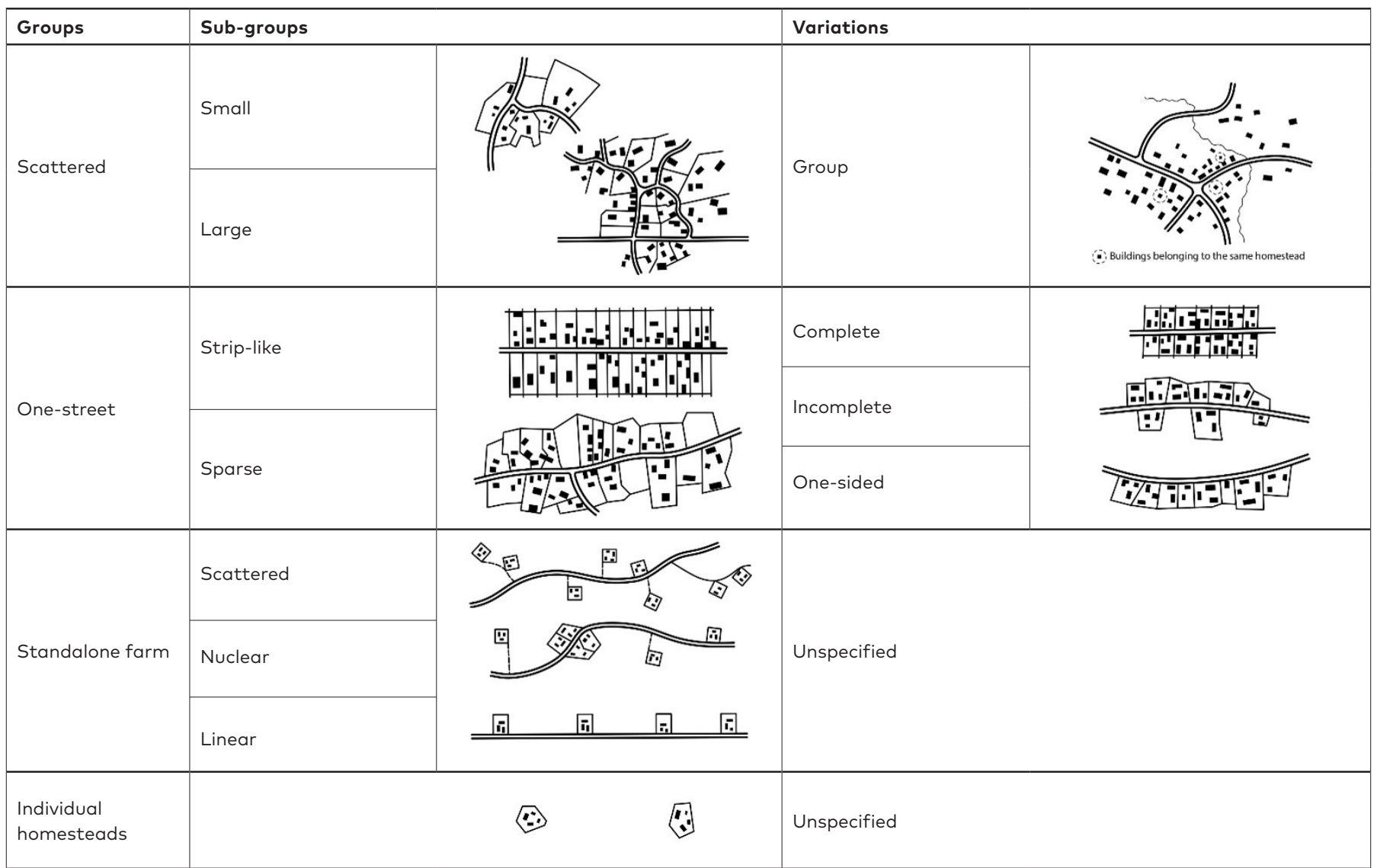


complexity of plan structure, this type of settlements was divided into two subgroups (small and large settlements) and an additional variation (group settlement). The onestreet settlements have a simple plan structure, dominated by one straight or slightly curved street, lined up by homesteads or other buildings. The one-street settlements were classified into two subgroups (strip-like and sparse) and three variations, according to the built-up completeness of the street front (complete, incomplete and one-sided). The standalone farm villages are composed of separate distantly placed homesteads and, according to their placement, can be divided into three subgroups (scattered, nuclear and linear), representing distinctive forms of sporadically built-up rural landscapes. Other types proposed by the researchers concerned rare cases and were considered unusual (e.g. individual homesteads). Although variations of the onestreet settlements were most numerous, the scattered form was considered as prior. The evolution and prevalence of different settlement forms greatly depended on various socio-economic factors, such as land-use and ownership reforms in rural areas [9]. This is illustrated by the fact that in the mid- $19^{\text {th }}$ century the proportion of one-street and standalone farm villages was similar, but during the first decades of the $20^{\text {th }}$ century the majority of older villages were dissolved into steadings, therefore the latter form began to dominate. Nevertheless, in the mid- $20^{\text {th }}$ century there were still some rural areas with prevailing older settlement forms, such as a small part of the eastern and south-eastern Lithuania, where one-street and scattered rural settlements remain common.

The typology of homesteads also interested researchers because they were considered as the most stable elements of the settlement's plan structure and most typical complexes of folk architecture. The main features defining the type of a homestead were its connection with the street, shape, organisation and position of the inner-yard, as well as functional and compositional inter-relation of the buildings [9]. Three types of homesteads were distinguished:

TABLE III

Types of Homesteads in Lithuanian Villages $[9,30]$

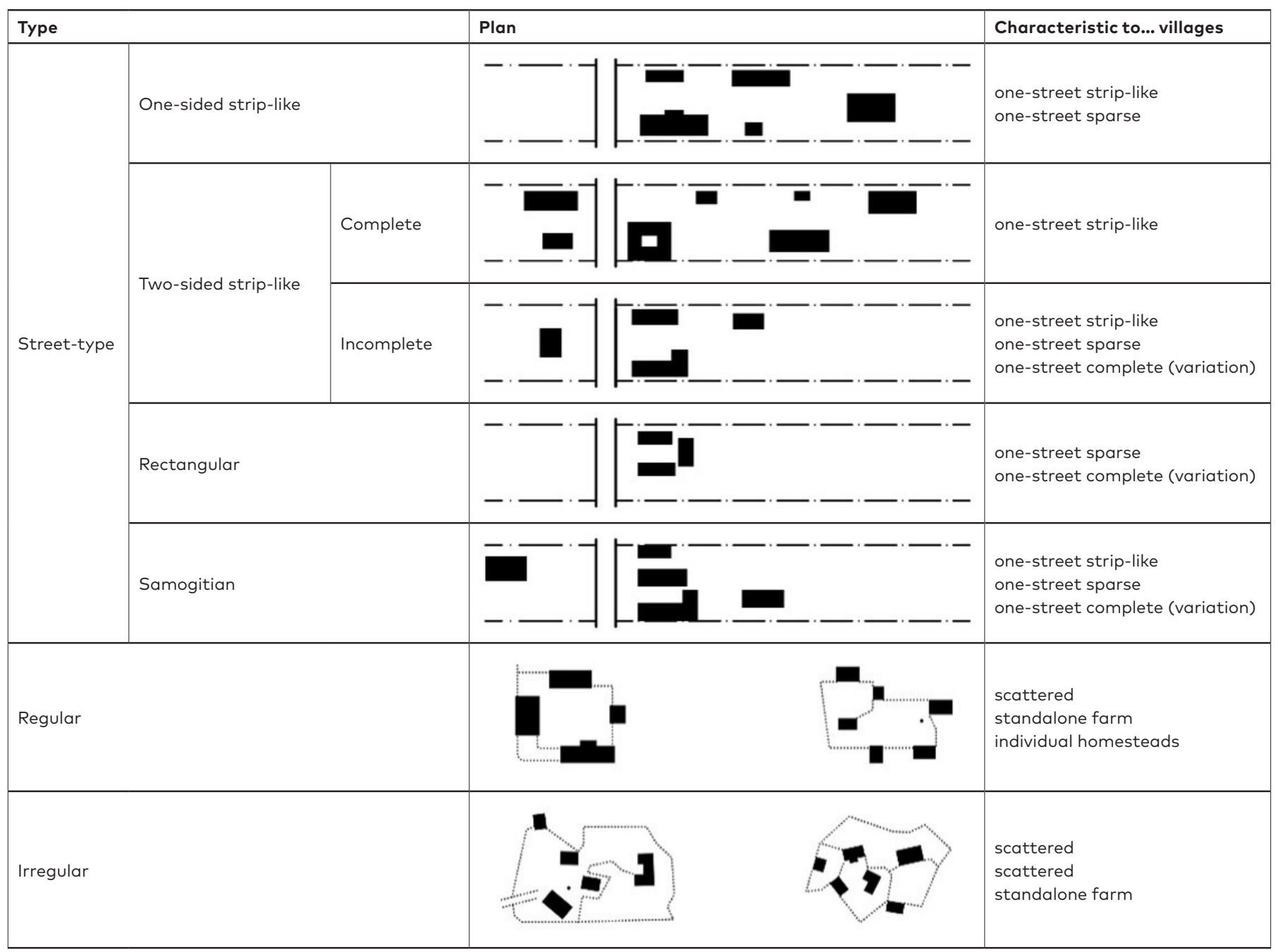


street-type, regular and irregular (Table III). The direct connection with the adjoining street is most obvious in the spatial organisation of a street-type homestead because its buildings form the street front. In scattered and standalone farm villages and individual homesteads the relation between the homestead and the street or access road is less significant than the arrangement of the buildings, which determines geometric regularity of the yard. Even if the inner organisation of homestead was primarily based on practical considerations, it was also influenced by the natural condition of the site and aesthetic preferences of the owner. For example, in the narrow plots of streettype homesteads, buildings were often built near the site's borders with its narrow sides facing the street, leaving space for gardens and passages. Spatial configuration and composition of homesteads on wider and larger plots were, on the contrary, more diverse and distinctive.

\section{B. Peculiarities of Urban Settlements}

Urban settlements have also fallen under the radar of the study of Lithuanian folk architecture because in these places local traditions and forms interacted with various historical-architectural styles. Towns evolved from the same early settlements as rural settlements, but the former eventually became more significant and acquired a more complex form. Nevertheless, town plans still resemble local architectural traditions. Since the formation of built-up structure and, subsequently, visual appearance of settlements is based on a plan, folk architecture has undoubtedly influenced urban forms. Therefore, the findings of the study of urban settlements were and continue to be useful for the planning of reconstruction and development of Lithuanian towns and cities.

The networks of arterial and subsidiary streets and the location of the settlement's centre were defined as the main distinctive features of the plan structure of Lithuanian towns. Based on the system of arterial streets, urban settlements in Lithuania were subdivided into three types: linear, radial and rectangular (Table IV). Taken separately, the network of subsidiary streets could be classified as undeveloped, multi-branch, rectangular, irregular or mixed. Depending on the location of the central square, two major variations of town plan were identified: (i) settlements with the central square positioned at the intersection of the main arterial streets and (ii) settlements with undeveloped centre

\section{TABLE IV}

Plan Types and Variations of Urban Settlements [10, 16]

\begin{tabular}{|c|c|c|c|c|c|c|c|c|c|}
\hline & \multirow[b]{3}{*}{ Plan types } & \multicolumn{8}{|c|}{ Variations } \\
\hline & & \multirow[b]{2}{*}{ Position of settlement's centre } & \multirow[b]{2}{*}{ Shape of central square } & \multicolumn{6}{|c|}{$\begin{array}{l}\text { Characteristics of subsidiary } \\
\text { street network }\end{array}$} \\
\hline & & & & 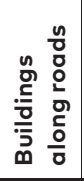 & 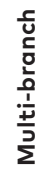 & 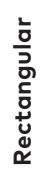 & 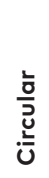 & $\begin{array}{l}\text { 흠 } \\
\text { ğ } \\
\text { 는 }\end{array}$ & 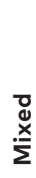 \\
\hline \multirow{3}{*}{ 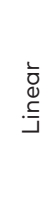 } & & \multirow{3}{*}{ Unspecified or undeveloped } & Quadrangular & + & + & + & & + & + \\
\hline & & & Widened street & + & + & + & & & \\
\hline & & & Undeveloped & + & & & & & \\
\hline \multirow{5}{*}{$\begin{array}{l}\overline{\overline{0}} \\
\overline{\bar{o}} \\
\bar{\alpha}\end{array}$} & & \multirow{5}{*}{$\begin{array}{l}\text { At the intersection of main arterial } \\
\text { streets or roads }\end{array}$} & Triangular & + & + & + & + & + & \\
\hline & & & Quadrangular & + & + & + & & + & \\
\hline & & & Widened street & + & & + & & + & \\
\hline & & & Irregular or multiple squares & + & + & + & + & + & + \\
\hline & & & Undeveloped & + & & + & & + & \\
\hline \multirow{3}{*}{ 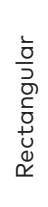 } & & \multirow{3}{*}{$\begin{array}{l}\text { At the intersection of main arterial } \\
\text { streets or roads }\end{array}$} & Quadratic & + & & + & & + & + \\
\hline & & & Quadrangular elongated & + & & + & & + & \\
\hline & & & Undeveloped & + & & + & & + & + \\
\hline
\end{tabular}


because the central square was located separately from major streets, therefore, less significant.

Differences in the plan structure have led to the formation of individual character of urban settlements. The linear plan is typical for small towns which are dominated by one arterial street, lined up with buildings and homesteads, with a widened segment of the main street or a rectangular square functioning as the settlement's centre. The rectangular plan is also more frequent in small towns. In this case, main arterial roads intersect perpendicularly, forming a rectangular central square, while other parts of the settlement are subdivided by an orthogonal network of subsidiary streets. The radial plan is found in urban settlements of various sizes. It is characterized by a compositionally-strong centre, from which arterial roads radiate. Due to the irregular intersection of major streets, the settlement's central square can acquire various more or less irregular multi-angular shapes and in some cases even a system of several squares can evolve.

The classification of urban settlements according to their plan structure into types and their variations is another achievement of the study of the Lithuanian folk architecture. It was identified that general trends of the country's social and economic development had been more significant for the evolution and distribution of different plan types in the Lithuanian territory than various local factors, such as natural conditions of the sites [10]. However, due to the abundance of radial-type cases, these spontaneously developed urban settlements were considered as characteristic in Lithuania. Although the rectangular-type settlements were also numerous, they were more frequent in Užnemune region (the area on the left bank of the Nemunas river), where due to the resettlement in the $15^{\text {th }}-18^{\text {th }}$ centuries new towns were built from scratch according to the then new urban design principles. Nevertheless, it was observed that in the mid- $20^{\text {th }}$ century almost half of the urban settlements in Lithuania were still at the initial stage of their development: without proper network of subsidiary (residential) streets, buildings concentrating just along major arterial streets.

Although the influence of folk architectural traditions is strong in smaller towns due to the weaker building regulation there, it is also visible in major cities, especially in their more or less spontaneously developed historical parts, where scenic street perspectives resemble inner urban spaces of small towns.

\section{Discussion}

As the article has shown, the development of both rural and urban settlements was largely influenced by external factors. Therefore, it can be assumed that the similarities and differences in these general development trends can provide a basis for comparing not only the settlement form characteristics itself, but the evolution of research field as well. The case of Lithuania revealed that during the second half of the $20^{\text {th }}$ century the initiation of urban form studies in smaller European countries might be dominated by particular research field or agenda, which can differ from common understanding of evolution of urban morphology in Western Europe, where the three independent research traditions (British, Italian, and French) emerged and flourished [22].

Due to the centralized nature of the Soviet regime, various scientific activities were ideologically and politically motivated. Perhaps this is precisely why a significant portion of research dealing with the cultural legacy has naturally shifted towards less controlled disciplines in the humanities and arts, thus leaving the obligation to carry out most of the 'relevant science' to the fields of social, technological and other sciences. The study of urban form, including its roots in the architectural branch within the folk culture research, is not an exception.

Partly based on the research tradition from the interwar period and furthermore stimulated by rapidly changing historical rural and urban landscapes, as well as disappearing local cultures, fading under the influence of post-war socialist modernisation, folk architecture research during the second half of the $20^{\text {th }}$ century presents a valuable repository for the study of urban form. Lithuanian researchers feverishly tried not only to document the most valuable cases of local architectural and urban forms but subsequently to condition reintegration of characteristic features into modern architecture and urbanism. The later attempt to practically use research findings might link the Lithuanian case to other urban morphology schools in Europe, for example, Italian typomorphological [23] or British historico-geographical [24] traditions. However, due to the partly independent development of urban form research in Lithuania, these possible ties need further investigation, but it is evident that interest in historical and architectural aspects of the development of rural and urban settlements in Lithuania has unfolded in parallel with the general European trends. Despite its local focus, the Lithuanian branch of urban form research could complement the regional and global landscape of urban morphology and contribute to the development of the field's scientific and practical methodology.

\section{Conclusions}

The evolution of urban form study in Lithuania is closely related to the country's urban development trends. Although interest in local rural and urban forms was not a new phenomenon, the research activities carried out during the second half of the $20^{\text {th }}$ century were distinguished by their intensity and complexity. Within this context, the field of folk architecture research acted as nurturing grounds for initiation and further development of settlements' form studies. 
The retrospective classification of rural settlements was one of the major achievements of the study of Lithuanian folk architecture. This complemented previous insular attempts to classify rural settlements by using rigorous attribute-based approach to defining most common types of pre-urban settlements (scattered, one-street and standalone farm villages) and their physical features (street network, homestead typology, etc.). Furthermore, further investigations revealed that prevalence of distinct settlement forms greatly depend on external socio-economic factors, especially, land-use and ownership reforms in rural areas. This resulted in regional disparities within relatively small area of the country and created characteristic rural landscapes (ethnographic localities) remaining to this day.

Historical towns were seldom built from scratch and evolve from pre-urban settlements, eventually acquiring a more complex form. They fascinated folk architecture researchers as locations where local traditions and forms interacted with diffusing architectural styles. Therefore, the classification of urban settlements in Lithuania according to their plan characteristics (network of arterial and subsidiary streets, location of settlement's centre) can be attributed to major achievements of the study of folk architecture as well. Differences in the plan structure have led to the formation of individual character (e.g. linear, radial and rectangular) of urban settlements. However, further research concluded that, similar to the case of rural settlements, distribution of plan types was heavily influenced by general social and economic development trends of the entire country. Furthermore, strict building and planning regulation eroded vast majority of pre-urban forms, except their spontaneously developed older parts, which still may resemble urban spaces of small towns and villages.

The material collected during the study of Lithuanian folk architecture is substantial not only for the knowledge and research of constantly disappearing cultural legacy of the nation, but also for its protection. Therefore, despite the unfulfilled hopes to use study findings in the formation of a specific local architectural language, the fundamental achievement of the study was organized efforts to establish protection of valuable objects of vernacular architecture [3]. The conducted research allowed to select and inventory the most valuable objects of rural architecture, preservation of which was extremely complicated due to the rapid social and spatial changes in rural areas. Therefore, outcomes of the study of Lithuanian folk architecture could be useful for the planning of reconstruction and development of rural and even urban settlements in Lithuania.

Characteristics and arguments behind the folk architecture research discussed in the article highlight a somewhat exceptional case of the emergence of settlement form studies. These initial investigations provided a sufficient material for the later development of urban form research in Lithuania. The research outcomes continue to possess an invaluable scientific, cultural, and practical significance. Furthermore, the rich archival material requires further analysis in order to integrate the methodology and results of these studies into the broader landscape of urban morphology.

\section{REFERENCES}

1. Whitehand, J. W. R. Urban morphology: how interdisciplinary? how international? Urban Morphology, vol. 22, no. 1, 2018, pp. 3-4.

2. Miškinis, A. Lietuvos urbanistika: istorija, dabartis, ateitis. Vilnius: Mintis, 1991. 153 p.

3. Šešelgis, K. Gyvenimas. Mokslo darbai. Vilnius: Technika, 2000. 280 p.

4. Getneris, J. Lietuvos miesteliai - mūsų urbanistinès kultūros šaltiniai. Naujoji Romuva, vol. 7, 1939, pp. 151-153.

5. Getneris, J. Lietuviškas sodžius - mūsų urbanistų mokytojas. Naujoji Romuva, vol. 11, 1940, pp. 221-223.

6. Motuzas, R. Algirdas Mošinskis ir Jurgis Getneris tarpukario Lietuvos paveldosaugos kontekste. Lietuvos istorijos studijos, vol. 40, 2017, pp. 36-52. https://doi.org/10.15388/LIS.2017.40.11611

7. Butkevičius, I. Lietuvių liaudies architektūros tyrinèjimų apžvalga. Lietuvos TSR architektūros klausimai, vol. I, 1960, pp. 142-155.

8. Galaunè, P. Lietuviu liaudies menas: jo meniniu formy plètojimosi pagrindai. Vilnius: Mokslas, 1988 (1930). 301 p.

9. Šešelgis, K., Baršauskas, J., Čerbulènas, K., Kleinas, M. Lietuvių liaudies architektūra I: kaimo gyvenvietès ir gyvenamieji namai. Vilnius: Mintis, 1965. 151 p.

10. Baršauskas, J., Čerbulènas, K., Jankevičienè, A., Minkevičius, J., Šešelgis, K. Lietuvių liaudies architektūra II: miesto gyvenvietès, visuomeniniai pastatai, ūkiniai ir gamybiniai trobesiai, buvusių dvarų sodybos. Vilnius: Mintis, 1968. 383 p.

11. Šešelgis, K. Nurodymai kaimu ir sodybu tyrimui. Vilnius: VISI gyvenviečių planavimo ir tvarkymo katedra, LTSR paminklų apsaugos ir kraštotyros draugija, 1978. 34 p.

12. Šešelgis, K. Lietuvių liaudies architektūros paminklai I: Zervynu kaimas. Vilnius: Periodika, 1974. 47 p.

13. Šešelgis, K., Urbelis, M. Lietuvių liaudies architektūros paminklai II: Maži padriki kaimai Lietuvos TSR nacionaliniame parke. Vilnius: Mokslas, 1980.131 p.

14. Šešelgis, K. Lietuvių liaudies architektūros paminklai III: Savaimingai susiklostę kaimai. Vilnius: Mokslas, 1988.101 p.

15. Šešelgis, K. Lietuvių liaudies architektūros paminklai IV: Pietryčiu Lietuvos gatviniai kaimai. Vilnius: Mokslo ir enciklopedijų leidykla, 1996. 247 p.

16. Šešelgis, K. Lietuvių liaudies architektūros paminklai V: Gatviniai ir vienkieminiai Aukštaitijos kaimai. Vilnius: Savastis, $1998.190 \mathrm{p}$.

17. Mortensen, H. Litauen, Grundzüge eines Landeskunde. Hamburg: L. Friederichsen \& Co., 1926. 59 p.

18. Lowmianski, H. Przyczynki do kwestij najstarszych ksztaltow wsi litewskiej. Ateneum Wilonskie, vol. IV, 1929.

19. Zaborski, B. Über Dorfformen und ihre Verbreitung. Breslau, 1930.127 p. 
20. Essen, W. Die ländlichen Siedlungen in Litauen mit besonderer Berücksichtigung ihrer Bevölkerungsverhältnisse. Leipzig: Voigtländers, $1931.133 \mathrm{p}$.

21. Tarvydas, S. Lietuvos TSR kaimu sodybu tipai ir ju pasiskirstymas. Vilnius: LTSR MA Geografijos institutas, 1948.

22. Moudon, A. V. Urban morphology as an emerging interdisciplinary field. Urban Morphology, vol. 1, 1997, pp. 3-10.

23. Marzot, N. The study of urban form in Italy. Urban Morphology, vol. 6, no. 2, 2002, pp. 59-73.

24. Whitehand, J. W. R. British urban morphology: the Conzenian tradition. Urban Morphology, vol. 5, no. 2, 2001, pp. 103-109.

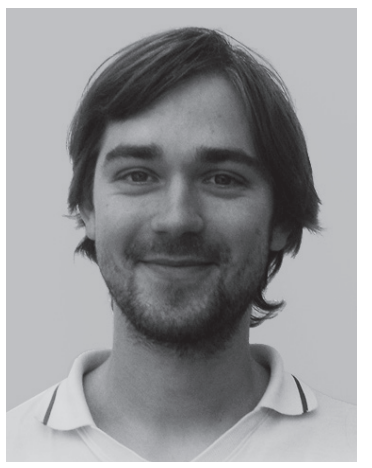

Matas Cirtautas received a degree of Doctor of Humanities in 2017 from Vilnius Gediminas Technical University (VILNIUS TECH). He is currently an Associated Professor at the Department of Urban Design, Faculty of Architecture, Vilnius Gediminas Technical University (VILNIUS TECH), where he teaches various urban design courses and supervises thesis projects. He is an author and co-author of several scientific studies (commissions) and publications. His research focuses on spatial transformations in large cities and their regions; urban design theory and practice with focus on spatial morphology and innovative modelling techniques.

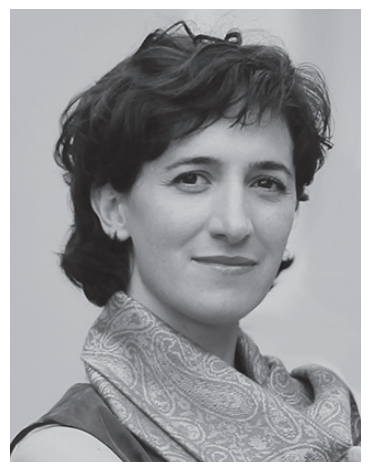

Inesa Alistratovaitè-Kurtinaitienè obtained a degree of Doctor of Humanities in 2005 from Vilnius Gediminas Technical University (VILNIUS TECH). She has been an Associate Professor with the Department of Urban Design of Faculty of Architecture, Vilnius Gediminas Technical University (since 2009), Head of the Laboratory of Urban Analysis (since 2014), where she is engaged in execution of individual scientific projects, research commissions, as well as preparation of architectural and urban design projects. She is an author and co-author of more than 40 projects. She was a guest lecturer at the Universities of Italy, Poland, Sweden, Finland, the Netherlands (2006-2019). She has presented reports at 24 international and national conferences. She is an author of 25 scientific publications. Her research inter- ests include urban structure and its transformation, urban morphology, protection and development of visual identity, GIS and other technological advancements in urban analysis. She is a member of the First Immovable Cultural Heritage Assessment Council (The Department of Cultural Heritage under the Lithuanian Ministry of Culture).

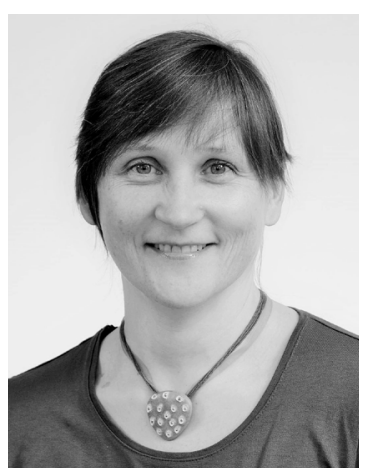

Dalia Dijokienè obtained the degree of Doctor of Humanities in 2002 from Vilnius Gediminas Technical University (VILNIUS TECH). She has been an Associate Professor with the Department of Urban Design of Faculty of Architecture, Vilnius Gediminas Technical University (since 2004), Head of the Department of Urban Design (since 2013). She was a guest lecturer at the Universities of Italy, Poland, Norway, Finland, United Kingdom, the Netherlands (2006-2021). She has been a practicing ARCHITECT since 1998. She is an author and co-author of more than 30 architectural projects. She has presented reports at 33 international and national conferences. She is an author of 45 scientific publications. Her research interests include historical urban development of town, historical suburbs, urban heritage, urban morphology, city and society. She is the Chairwoman of the Second Immovable Cultural Heritage Assessment Council (The Department of Cultural Heritage under the Lithuanian Ministry of Culture) and a member of the Council of the Lithuanian Chamber of Architects.

\section{Contact Data}

\section{Matas Cirtautas}

E-mail: matas.cirtautas@vilniustech.lt

Inesa Alistratovaitè-Kurtinaitienè

E-mail: inesa.alistratovaite-kurtinaitiene@vilniustech.lt ORCID iD: https://orcid.org/0000-0002-7414-1186

\section{Dalia Dijokienè}

E-mail: dalia.dijokiene@vilniustech.lt

ORCID iD: https://orcid.org/0000-0003-2933-2669 